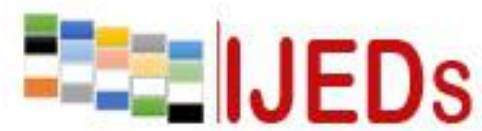

http://ijeds.ppj.unp.ac.id/index.php/IJEDS

\title{
THE INCREASE IN THE RESULTS OF THE STUDY AND THE ACTIVITY OF LEARNERS THROUGH THE METHOD OF DISCOVERY LEARNING IN MATHEMATICS
}

\author{
*Miza Emylina \\ Graduate Program of Education \\ Faculty of Science, Universitas Negeri Padang, Indonesia \\ Email : mizaemylina87@gmail.com
}

*Corresponding Author, Received: November 12, 2018, Revised: December 10, 2018, Accepted: December 21, 2018

\begin{abstract}
The background study of mathematics in the sixth grade at SDN 10 Nan Balimo districk of Tanjung Harapan Solok city,where teachers mostly use the lecture method and learning tasks.During these learning out comes visible only from the ability of learnes to memorizefacts. Although many students are able to present a good level of memorization of the material it receives, but in reality they often do not understand in depth the substance of the material.Therefore conducted research in the form of precycle,cycle I and cycle II. There are four important satges in this action research,that is: (1) Design, (2) implementation, (3) observation, (4) reflection at SDN 10 Nan Balimo, changes in learning shown by mastering by learnes. Effective learning activities cannot appear by itself but the teacher should be able to create learning that enables learnes archieve the goals that have been set optimally,improvement of learning out comes of student and interest of learnes to be able to understand learning materials using a makeshift media and methods that are less precise at first was somewhat less but after improvements both in terms of teaching methode and used the students interest and understanding of the learning material has begin to rise, and with the use of mathematical methods of discovery learning outcomes of students at SDN 10 Nan Balimo already increased due to the discovery method required students to find themselves in everyday life.
\end{abstract}

Keywords : Learning Outcome, Methods of Discovery, Learning of Mathematics

\section{INTRODUCTION}

The problem now is how to find the best way to convey various concepts being taught in a particular subject, so that all students can use and remember more old concepts that has been implemented identify the shortcomings of the learning that has 


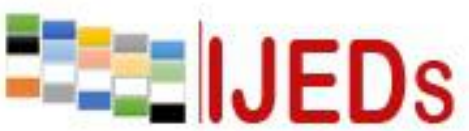

http://ijeds.ppj.unp.ac.id/index.php/IJEDS

been implemented identify the shortcomings of the learning that has been implemented identify the shortcomings of the learning that has been implemented identify the shortcomings of the learning that has been implemented, discussions then found some problems that occurred during the learning process takes place that is, the first; Learners are less understanding of the material due to the method used is less relevant in learning learning learner results so low. Second; An interesting use of media that can are use the learning motivation of learners, The third; Learners still have not been able to understand the material about the scale and comparison of learning outcomes so that learners are low.

Through discussion and question and answer with supervisor diketahuilah cause factor of the low learning outcomes students are: a. The teacher less using learning methods of learning relevant to the material being presented. Teachers are more often using methods lectures so that learning less appealing and makes learners meribut classroom learning while it lasts. b. Learners only assignee be reserved-math problems without any faqs with the from 2 s.d 3 meetings.

This research was conducted on Class VI students of SDN 10 Nan Balimo, Solok City, totaling 28 people and 1 observer for 2 months starting from March to May 2014. The research approach was a qualitative descriptive approach which was assisted by a quantitative approach in the form of percentage. Qualitatively the data is analyzed through 3 steps, namely: 1) data reduction is done through selection, grouping and organizing raw data into meaningful information; 2) data exposure, in the form of clear and easily understood data in the form of graphs and narrative exposures; 3 ) inference, extracting the essence from the presentation of data that has been organized in the form of short, solid and meaningful sentences.

This research activity was carried out in the form of a Pre Cycle, then cycle I and cycle II. There are four important stages in this action research, namely: (1) planning, (2) Implementation, (3) Observation and (4) Reflection (Hermon and Dalim, 2005; Hermon and Dalim, 2006; Arikunto et al., 2006). a. Shake hands with the teacher and say hello; b. Pray; c. Checking the attendance of students conditions the seating of students; d. Apperception: Ask questions with students about the comparison and scale on the map 2. Core Activities. a. The teacher attracts the attention of students; $b$. The 


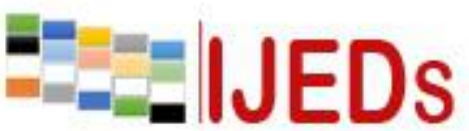

http://ijeds.ppj.unp.ac.id/index.php/IJEDS

\section{International Journal of Educational Dynamics}

Vol. 1 No. 1 (pp. 131-135) December 2018

p_ISSN 2655-4852

e ISSN 2655-5093

teacher exemplifies the basic way of using the media; c. The teacher assigns students to carry out activities to determine the scale and comparison; $d$. students can ask questions with the teacher about the unit; e. Give opportunities to students to show performance in the future; f. Give students the opportunity to ask questions; g. Provide opportunities for students to answer questions; h. Provide opportunities for students to complete the answers of students

\section{METHOD}

This research includes research into the class Act (Clasroom Action Research) through the 4 stages: Preparation (planning), Implementation of learning (action), observation of learning activities (observation) and evaluation of processes and results of reflection (reflection). This research is planned for 2 cycles and each cycle is set to achieve $1 \mathrm{KD}$ consisting In the first cycle begins with: a. planning action, making learning scenarios with based learning methods Discovery, provides necessary equipment, teaching materials, tools data collector in the form of a guide observation, observation sheets and field notes; b) implementation of actions in accordance with the scenario prepared.

\section{RESULTS AND DISCUSSION}

The results showed that the learning outcomes of students showed an increase from pre-cycle to the implementation of the second cycle because the learning activities of students from pre-cycle. The trend of changes in student learning outcomes is presented, with only $20 \%$ meeting the KKM, which is $\geq 70$ before the study becomes $90 \%$ after the study. The research began with an initial reflex by the teacher who conducted the research, namely showing the activities and student learning outcomes that had occurred before this research activity was carried out.

Based on the implementation and observations it appears that still learning cycle 1 with the steps to improve learning that will be done is: - Providing relevant media; - Creating interesting situations and conditions for students to do learning in accordance with the Discovery method In Table 3, the data on the learning activities of 


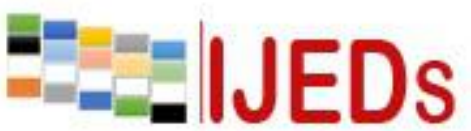

http://ijeds.ppj.unp.ac.id/index.php/IJEDS
International Journal of Educational Dynamics

Vol. 1 No. 1 (pp. 131-135) December 2018

p_ISSN 2655-4852

e ISSN 2655-5093

students were recapitulated by the observer and in table 4 the data on the learning outcomes of students through evaluation at the end of cycle 2. If compared between tables 1 and 4 shows that there is a slight increase in the number of students value above 70. a. At the end of the lesson so the teacher asks the students if there are learning concepts from material that are less clear or poorly understood; b. Re-explain material concepts that are not understood by students; c. Guidance from teachers to be more intensified. Suggestions from the observer were made as a refinement of the learning stages in the second cycle, as a recycling of learning steps in the cycle 1. Data on student learning activities and the student learning outcomes suggested by the observer are illustrated in tables 5 and 6.

Changes in student learning outcomes are seen through Discovery-based learning so that student competencies improve which has an impact on increasing student learning outcomes. The refinement of the curriculum should be done to respond to the demands of the increasing kualitaspendidikan and learning. Viewed from the objective, curriculum unit level education (KTSP) want to focused on the development of the entire competence of learners. The students are assisted.

In view of the fact that there are in the field at this present moment many among learners who lack understanding of the material sehinggga resulting in learners learning results is significantly lower, Similarly on SDN 10 Nan Balimo where researchers in charge of processed VI consisting of 20 students from the results answer the question asked of teachers through the method of questioning. Similarly on SDN 10 Nan Balimo where researchers in charge of processed VI consisting of 20 students from the results answer the question asked of teachers through the method of questioning. Based on the fact that the author at once as a teacher trying to hold improvement of learning through the use of methods of discovery where students could find himself through the life of a day - a day to be able to improve the learning results of learners. Based on the above, the researcher's colleagues to friends asking for help identify the shortcomings of the learning teacher. 


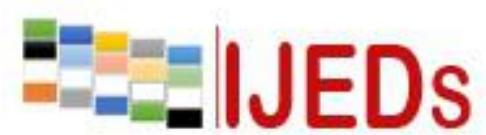

http://ijeds.ppj.unp.ac.id/index.php/IJEDS

\section{International Journal of Educational Dynamics}

Vol. 1 No. 1 (pp. 131-135) December 2018

p_ISSN 2655-4852

e ISSN 2655-5093

\section{CONCLUSION}

This study concludes that improving student learning outcomes through discovery-based learning has been carried out and provides excellent results, namely by increasing student learning outcomes and activities of students in learning in class VI SDN 10 Nan Balimo, Solok City. Based on the conclusions above, there are some things that teachers should do in improving the quality of learning, especially to improve the activities and learning outcomes of students in learning, namely: 1. Choosing the right learning method; 2. Optimizing tools and media that can attract students' attention; 3. Motivating and testing students based.

\section{REFERENCES}

Cornellius. 1999. Mathematics. Jakarta: Ministry of Education and Culture

Ministry of National Education. 2006. Education Unit Level Curriculum. Jakarta: Ministry of National Education

Abin, Syamsudin, M.A et al. 2002. Teaching Profession II. Jakarta: Open University

Hamalik, O. 2003. Teaching Planning. Jakarta: Bumi Aksara Internet, www.menulis.co.id

Hermon, D and Y. Dalim. 2005. Penggunaan Media Audio Visual untuk Meningkatkan Kreatifitas Belajar. Jurnal Pembelajaran. Vol. 28. Issue 3. p. 266-276

Hermon, D and Y. Dalim. 2006. Penerapan Kuliah Lapangan untuk Meningkatkan Hasil Belajar Mahasiswa. Forum Pendidikan. Vol. 28. Issue 3. p. 156-161

Usman, U. 1995. Being a Professional Teacher, Bandung: PT Remaja Rosdakarya Simanjuntak, L. et al. 1992. Mathematics Teaching Methods. Rineka Cipta: Bandung Nana, S. 1979. Educational Basics, Jakarta: Earth Literacy Wardani, I et al. 2007. Research on Classroom Action. Jakarta: Open University 